\title{
Onchocerciasis in Ecuador: Prevalence of Infection on the Ecuador-Colombia Border in the Province of Esmeraldas
}

\author{
Joy R Guderian, Mariela Anselmi, Mauricio Espinel, Carlos Sandoval, \\ Philip J Cooper, Gonzalo Rivadeneira*, Ronald H Guderian/ ${ }^{+}$
}

\author{
National Onchocerciasis Control Program, Hospital Vozandes, HCJB Casilla 17-17-691, Quito, Ecuador \\ *Dirección Nacional de Epidemiología, MSP, Quito, Ecuador
}

The prevalence of onchocerciasis infection was determined in communities on 7 rivers located in the northern area of the cantón San Lorenzo, province of Esmeraldas. Diagnosis of the infection was obtained by skin biopsies and recombinant-antigen based-serology. No evidence of infection was detected in 9 communities studied along the Río Mataje, which forms the frontier between Ecuador and Colombia, nor in 10 adjacent communities located on 5 interior rivers. Evidence for Onchocerca volvulus infection was found in 4 communities on the Rio Tululvi with the following prevalence: La Boca (3.5\% by biopsy and 3.9\% by serology), Guayabal (9.1\% by both biopsy and serology), La Ceiva (51.5\% by biopsy and $53 \%$ by serology), and Salidero (4\% by biopsy and $7.7 \%$ by serology). A few individuals in these communities were seropositive for $\mathrm{O}$. volvulus in the absence of detectable dermal microfilariae: these might harbor very light or prepatent infections. No clinical disease attributable to onchocerciasis was found. The infected communities will be included in the ivermectin-based National Control Program for the disease, with no evidence of the infection having extended north of the Ecuadorian-colombian border.

Key words: onchocerciasis - prevalence - Ecuador - Colombia - migration

Onchocerciasis is a filarial infection of humans caused by infection with Onchocerca volvulus which is transmitted by blackflies of the genus Simulium. It is an important cause of ocular and skin pathology in Africa and the Americas. The first case of onchocerciasis in Ecuador was documented in 1980, in a black male from the province of Esmeraldas (Carvajal \& Zerega 1980). Epidemiological studies have determined the geographical location of the infection (Guderian et al. 1983), the prevalence and intensity of infection (Guderian et al. 1988a, 1989, 1990), its clinical manifestations (Guderian et al. 1984), and the principal vectors involved in the transmission of the disease (Shelley \& Arzube 1985, Shelley et al. 1989).

The principal endemic focus in the province of Esmeraldas, is located in the Santiago River Basin which is formed by the union of 3 main rivers: Río Cayapas, Río Onzoles, and Río Santiago, and their tributaries (Guderian et al. 1983). Due to the no-

\footnotetext{
This work was supported by the Christoffel Blindenmission, River Blindness Foundation, Vicariato Apostólico de Esmeraldas and the Onchocerciasis Project, Hospital Vozandes.

${ }^{+}$Corresponding author. Fax: +593-2-447-263

Received 12 September 1996

Accepted 18 November 1996
}

madic nature of many infected individuals and the ubiquitous presence of the primary vector in Ecuador, there is the risk of extension of the disease to other parts of the country. Satellite foci along several rivers in the southern part of the province have already been reported. These have developed due to migration of infected individuals from the principal focus (Guderian et al. 1987).

Over the past 10 years, young Chachi males infected with $O$. volvulus have migrated to the rivers located in cantón San Lorenzo, in the northern section of the province (Guderian et al. 1987). The majority settled in or close to the community of $\mathrm{La}$ Ceiva along the Río Tululví have maintained constant contact with the other communities on this and other rivers in the area. The first epidemiological study done in 1986 showed evidence of active transmission of the infection in the communities located in this cantón (Guderian et al. 1988b). To determine if the disease had extended to the Colombian-ecuadorian border, a study was done in 1994 to determine the prevalence of infection in the communities located in the northern section of the cantón San Lorenzo.

\section{MATERIALS AND METHODS}

Study area - The province of Esmeraldas, latitude $1^{\circ} 96^{\prime} \mathrm{S}$ to $1^{\circ} 43^{\prime} \mathrm{N}$ and longitude $78^{\circ} 48^{\prime} \mathrm{W}$ to $80^{\circ} 9^{\prime} \mathrm{W}$, is situated west of the Andes, in the northwestern region of Ecuador. The cantón San 
Lorenzo is the most northern cantón of the province and lies adjacent to the Department of Nariño in Colombia (Fig.). A total of 27 communities located along 7 rivers was studied. These rivers included: Río Mataje which forms the border between Ecuador and Colombia, and the rivers Palaví, Tululví, Guadualito, Najurungo and El Sande which are tributaries of the Río Bogotá.

All surveys were performed with the assistance of the local community health workers (WHO 1991). A house-to-house census was compiled for each community and campaigns to educate the communities about onchocerciasis and its treatment and control were also performed. Members, 5 years and older, of all households were invited to participate in the study.

Clinical examination - A complete physical examination was performed on each participant at the start of the study. An experienced physician examined each subject for the presence of onchocercal nodules and skin disease. Ocular assess- ment included measurement of visual acuity and slit-lamp examination of the anterior segment and direct ophthalmoscopy of the posterior segment.

Diagnosis - Two methods were used: skin biopsies to detect the presence of microfilariae, and serology (ELISA).

Skin biopsies - Skin biopsies were taken from both iliac crests using a Holth corneoscleral punch, as previously described (Guderian et al. 1983). Each biopsy was placed in a microtiter well with $0.9 \%$ saline, and the number of emergent microfilariae were counted after $24 \mathrm{hr}$ using an inverted microscope.

Serology - To detect prepatent or cryptic infections an ELISA-based assay, which used a cocktail of 3 recombinant antigens show to have a high specificity and sensitivity was performed (Bradley et al. 1993). Finger-prick capillary samples were collected on filter paper, dried, and stored at $-20^{\circ} \mathrm{C}$ before testing. ELISA plates were coated with a cocktail of three recombinant antigens in

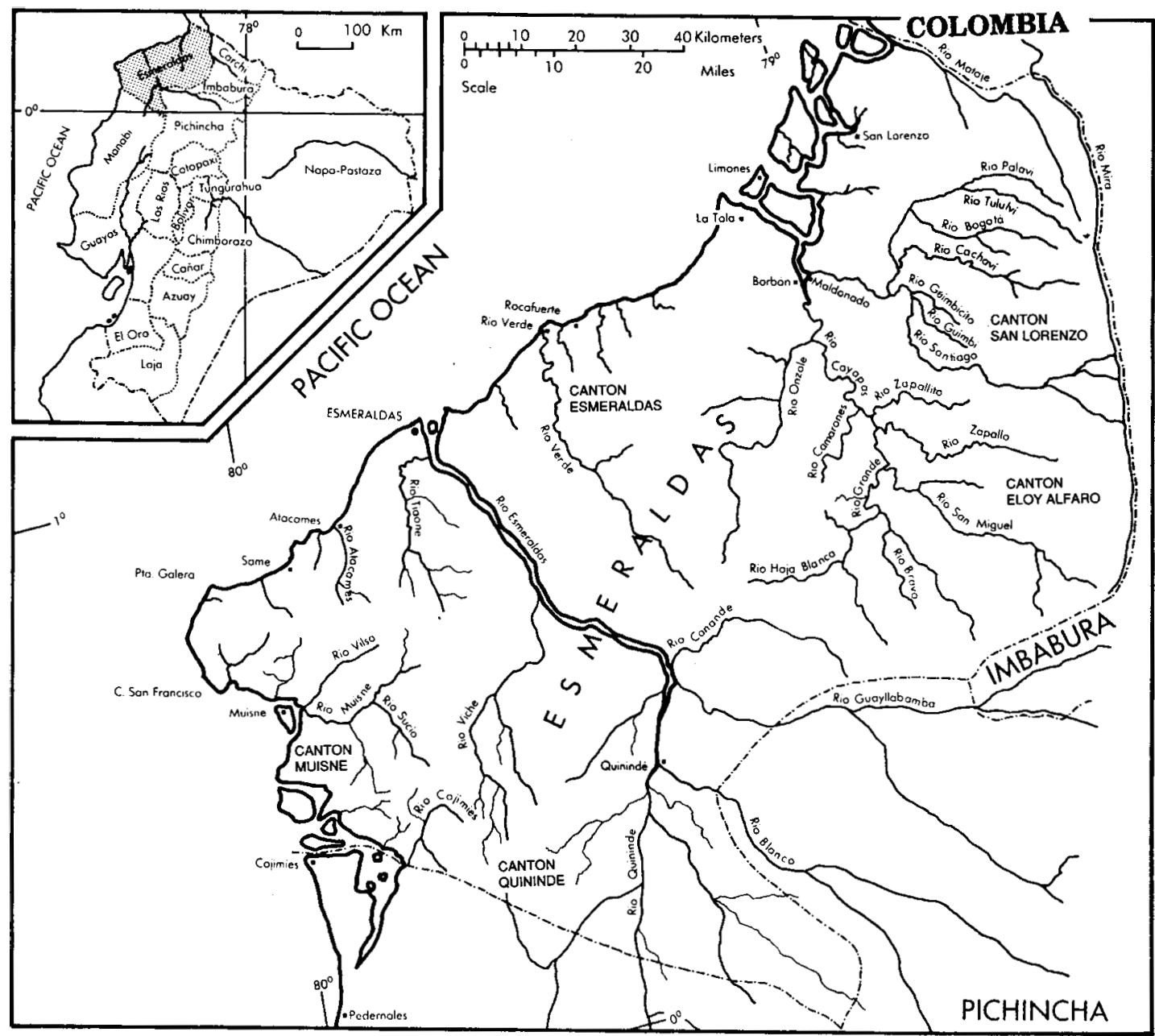

Province of Esmeraldas showing the different cantons, endemic areas for onchocerciasis. 
$0.05 \mathrm{M}$ carbonate buffer, $\mathrm{pH}$ 9.6. The final concentration was $2 \mu \mathrm{g} / \mathrm{ml}$ in the proportion of $50 \%$ Ov $11,25 \%$ Ov 10 , and $25 \%$ Ov 29 (Ov 10 and Ov $29,500 \mathrm{ng} / \mathrm{ml}$; and Ov $11,1 \mu \mathrm{g} / \mathrm{ml})$. The ELISA methodology, which has been reported previously (Bradley et al. 1991, 1993), was performed with the following modifications. The plates were blocked for $1 \mathrm{hr}$ with 5\% nonfat skim milk in PBS and serum samples were added at 1/200 dilution in $0.05 \%$ Tween 20 (PBS-T) with 5\% nonfat skim milk. The secondary and tertiary antibody binding steps were performed in PBS-T alone. The second antibody was anti-human IgG (clone no. MO 6014; Oxoid, New York, NY) monoclonal antibody and the third was anti-mouse peroxidase conjugate (p260; Dakopatts, Copenhagen, Denmark). The plates were developed with 2,2'-azino-di-(ethyl benzathiozoline) substrate (Sigma, St.Louis, MO). A positive test was determined as previously described (Bradley et al. 1993).

\section{RESULTS}

Demography - Between $72 \%$ and $95.1 \%$ of the eligible population of each community were examined (Table I). The communities in this cantón are unstable due to constant migration to other geographical regions. The communities located towards the headwaters of Río Mataje and those situated on Río Palaví are populated by indigenous Amerindians, the Awas. As the majority of the tribe live in Colombia, there was constant migration of persons and families between the two countries. Migration of Afro-ecuadorians from the coast led to the recent establishment of the community of Salidero on the Río Tululví. Elsewhere, in Afroecuadorian communities located on different rivers, there was a marked migration of young Afroecuadorians to the coastal cities in search of employment.

Prevalence of infection - No evidence of infection (by biopsy or serology) was seen in any of the

TABLE I

Prevalence of onchocerciasis in communities studied in the cantón San Lorenzo, province of Esmeraldas, 1994

\begin{tabular}{|c|c|c|c|c|c|c|c|}
\hline \multirow[t]{2}{*}{ Location } & \multirow{2}{*}{$\begin{array}{c}\text { Total } \\
\text { population }\end{array}$} & \multicolumn{2}{|c|}{ Persons examined } & \multicolumn{2}{|c|}{ Biopsy (+) } & \multicolumn{2}{|c|}{ Serology (+) } \\
\hline & & No. & $(\%)$ & No. & (\%) & No. & $(\%)$ \\
\hline \multicolumn{8}{|l|}{ RIO MATAJE } \\
\hline Campenita & 64 & 47 & 73.4 & 0 & 0.0 & 0 & 0.0 \\
\hline Garcia & 7 & 6 & 85.7 & 0 & 0.0 & 0 & 0.0 \\
\hline Mataje & 102 & 97 & 95.1 & 0 & 0.0 & 0 & 0.0 \\
\hline Valverde & 12 & 10 & 83.3 & 0 & 0.0 & 0 & 0.0 \\
\hline Las Delicios & 26 & 20 & 76.9 & 0 & 0.0 & 0 & 0.0 \\
\hline Campana & 12 & 10 & 83.3 & 0 & 0.0 & 0 & 0.0 \\
\hline El Pan & 129 & 103 & 79.8 & 0 & 0.0 & 0 & 0.0 \\
\hline La Redonda & 48 & 39 & 81.2 & 0 & 0.0 & 0 & 0.0 \\
\hline Casa Comunal & 52 & 45 & 86.5 & 0 & 0.0 & 0 & 0.0 \\
\hline \multicolumn{8}{|l|}{ RIO PALAVI } \\
\hline Pambilar & 64 & 49 & 76.6 & 0 & 0.0 & 0 & 0.0 \\
\hline Balzareño & 60 & 45 & 75.5 & 0 & 0.0 & 0 & 0.0 \\
\hline \multicolumn{8}{|l|}{ RIO TULULVI } \\
\hline La Boca & 303 & 258 & 85.1 & 9 & 3.5 & 10 & 3.9 \\
\hline Guayabal & 67 & 55 & 82.1 & 5 & 9.1 & 5 & 9.1 \\
\hline La Ceiva & 78 & 66 & 84.6 & 34 & 51.5 & 35 & 53.0 \\
\hline Salidero & 84 & 65 & 77.4 & 3 & 4.6 & 5 & 7.7 \\
\hline \multicolumn{8}{|c|}{ RIO GUADUALITO } \\
\hline Guadualito & 118 & 85 & 72.0 & 0 & 0.0 & 0 & 0.0 \\
\hline \multicolumn{8}{|l|}{ RIO BOGOTA } \\
\hline Carondelet & 208 & 167 & 80.3 & 0 & 0.0 & 0 & 0.0 \\
\hline Santa Rita & 276 & 191 & 69.2 & 0 & 0.0 & 0 & 0.0 \\
\hline San Francisco & 489 & 398 & 81.4 & 0 & 0.0 & 0 & 0.0 \\
\hline Calderon & 245 & 178 & 72.7 & 0 & 0.0 & 0 & 0.0 \\
\hline Ricaute & 693 & 563 & 81.2 & 0 & 0.0 & 0 & 0.0 \\
\hline \multicolumn{8}{|c|}{ RIO NAJURUNGO } \\
\hline Najurungo & 90 & 75 & 83.3 & 0 & 0.0 & 0 & 0.0 \\
\hline \multicolumn{8}{|l|}{ RIO EL SANDE } \\
\hline El Sande & 98 & 80 & 81.6 & 0 & 0.0 & 0 & 0.0 \\
\hline
\end{tabular}


communities along the rivers Mataje, Palaví, Guadualito, Bogotá, Najurungo and El Sande (Table I). O. volvulus microfilariae were found only among members of the 4 communities located on Río Tululví. The prevalence of infection, stratified by sex and age, in these positive communities is given in Tables II and III. The prevalence of onchocerciasis in the community of La Boca was $3.5 \%$ by biopsy and $3.9 \%$ by serology which included both adults and children. One subject was negative by skin snips and positive by serology. An increased rate of infection (9.1\%) was seen in Guayabal, where only adults, both male and female, were infected. The Chachi Amerindian community of La Ceiva had the highest prevalence of infection ( $51.5 \%$ by biopsy and $53 \%$ by serology). All age groups were affected and one subject had negative skin biopsy but positive serology. The recent established community of Salidero, which was located the furthest upriver, had the lowest prevalence of infection (4.6\% by biopsy and $7.7 \%$ by serology). All those affected were adults and two individuals were positive by serology alone.

Clinical disease - No evidence of clinical disease attributable to $O$. volvulus infection was seen in any of the communities studies.

\section{DISCUSSION}

The risk of onchocerciasis spreading from its primary focus in the Santiago Basin to other regions in the province of Esmeraldas has been a concern for many years. The spread of the infection seems to occur primarily through the migration of infected individuals to non-endemic areas where the vector is known to exist (Guderian et al. 1987). In recent years, the northern region of the cantón San Lorenzo has experienced several population influxes: Chachi families from Río Cayapas; the Awa Indians from Colombia; and migrant workers involved in logging. There has been concern that onchocerciasis might expand into adjacent regions of Colombia (Guderian \& Shelley 1992).

The sensitivity of the skin snips to detect an active infection is low when the microfilariae skin density is low (less than $5 \mathrm{mf} / \mathrm{mg}$ ) (Collins et al. 1980), which is a common finding in recently infected areas. Positive serology indicates exposure to the parasite but is unable to differentiate past exposure from current infection. Seropositivity in the absence of detectable microfilariae in skin snips might indicate low parasite densities or prepatent infections. Positive serology with or without skin snips in children is suggestive of autochthonous transmission, as children are less likely to acquire the disease elsewhere (through work or migration).

La Ceiva on Río Tululví was probably the community through which onchocerciasis was introduced into the area (Guderian et al. 1983). Young Chachi adults infected with the disease migrated to this area from Río Cayapas, a hyperendemic

\section{TABLE II}

Prevalence of onchocerciasis in individuals according to age and sex in the communities La Boca and Guayabal located on the Río Tululví, province of Esmeraldas, 1994

\begin{tabular}{|c|c|c|c|c|c|c|c|}
\hline \multirow{3}{*}{$\begin{array}{l}\text { Sex } \\
\text { age }\end{array}$} & \multicolumn{5}{|c|}{ Prevalence } & \multirow{2}{*}{\multicolumn{2}{|c|}{ Serology (+) }} \\
\hline & \multirow{2}{*}{$\begin{array}{c}\text { Total } \\
\text { population }\end{array}$} & \multicolumn{2}{|c|}{ Persons examined } & \multicolumn{2}{|c|}{ Biopsy (+) } & & \\
\hline & & No. & $(\%)$ & No. & $(\%)$ & No. & $(\%)$ \\
\hline LA BOC & & & & & & & \\
\hline Total & 303 & 258 & 85.1 & 9 & 3.5 & 10 & 3.9 \\
\hline Male & 150 & 130 & 86.6 & 4 & 3.1 & 5 & 3.8 \\
\hline $5-12$ & 54 & 51 & 94.4 & 2 & 3.9 & 3 & 5.9 \\
\hline $13-19$ & 33 & 31 & 93.9 & 0 & 0.0 & 0 & 0.0 \\
\hline $20+$ & 63 & 48 & 76.2 & 2 & 4.2 & 2 & 4.2 \\
\hline Female & 153 & 128 & 83.7 & 5 & 3.9 & 5 & 3.9 \\
\hline $5-12$ & 57 & 53 & 93.0 & 2 & 3.8 & 2 & 3.8 \\
\hline $13-19$ & 21 & 17 & 81.0 & 1 & 5.9 & 1 & 5.9 \\
\hline $20+$ & 75 & 58 & 77.3 & 2 & 3.4 & 2 & 3.4 \\
\hline GUAYA & & & & & & & \\
\hline Total & 67 & 55 & 82.1 & 5 & 9.1 & 5 & 9.1 \\
\hline Male & 33 & 28 & 84.8 & 3 & 10.7 & 3 & 10.7 \\
\hline 5-12 & 12 & 11 & 91.7 & 0 & 0.0 & 0 & 0.0 \\
\hline $13-19$ & 2 & 1 & 50.0 & 0 & 0.0 & 0 & 0.0 \\
\hline $20+$ & 19 & 16 & 84.2 & 3 & 18.8 & 3 & 18.8 \\
\hline Female & 34 & 27 & 79.4 & 2 & 7.4 & 2 & 7.4 \\
\hline $5-12$ & 9 & 7 & 77.8 & 0 & 0.0 & 0 & 0.0 \\
\hline $13-19$ & 4 & 1 & 25.0 & 0 & 0.0 & 0 & 0.0 \\
\hline $20+$ & 21 & 19 & 90.5 & 2 & 10.5 & 2 & 10.5 \\
\hline
\end{tabular}


TABLE III

Prevalence of onchocerciasis in individuals according to age and sex in the communities La Ceiva and Salidero located on the Río Tululví, province of Esmeraldas, 1994

\begin{tabular}{|c|c|c|c|c|c|c|c|}
\hline \multirow{3}{*}{$\begin{array}{l}\text { Sex } \\
\text { age }\end{array}$} & \multicolumn{5}{|c|}{ Prevalence } & & \\
\hline & \multirow{2}{*}{$\begin{array}{c}\text { Total } \\
\text { population }\end{array}$} & \multicolumn{2}{|c|}{ Persons examined } & \multicolumn{2}{|c|}{ Biopsy (+) } & \multicolumn{2}{|c|}{ Serology (+) } \\
\hline & & No. & $(\%)$ & No. & $(\%)$ & No. & $(\%)$ \\
\hline \multicolumn{8}{|c|}{ LA CEIVA } \\
\hline Total & 78 & 66 & 84.6 & 34 & 51.5 & 35 & 53.0 \\
\hline Male & 45 & 40 & 88.9 & 22 & 55.0 & 23 & 57.5 \\
\hline $5-12$ & 14 & 13 & 92.9 & 2 & 15.4 & 2 & 15.4 \\
\hline $13-19$ & 15 & 12 & 80.0 & 9 & 75.0 & 10 & 83.3 \\
\hline $20+$ & 16 & 15 & 93.8 & 11 & 73.3 & 11 & 73.3 \\
\hline Female & 33 & 26 & 78.8 & 12 & 46.2 & 12 & 46.2 \\
\hline $5-12$ & 7 & 7 & 100.0 & 0 & 0.0 & 0 & 0.0 \\
\hline $13-19$ & 11 & 6 & 54.5 & 3 & 50.0 & 3 & 50.0 \\
\hline $20+$ & 15 & 13 & 86.7 & 9 & 69.2 & 9 & 69.2 \\
\hline \multicolumn{8}{|c|}{ SALIDERO } \\
\hline Total & 84 & 65 & 77.4 & 3 & 4.6 & 5 & 7.7 \\
\hline Male & 48 & 36 & 75.5 & 2 & 5.6 & 3 & 8.3 \\
\hline $5-12$ & 17 & 12 & 70.6 & 0 & 0.0 & 0 & 0.0 \\
\hline $13-19$ & 6 & 5 & 83.3 & 1 & 20.0 & 1 & 20.0 \\
\hline $20+$ & 25 & 19 & 76.0 & 1 & 5.3 & 2 & 10.5 \\
\hline Female & 36 & 29 & 80.6 & 1 & 3.4 & 2 & 6.9 \\
\hline $5-12$ & 10 & 8 & 80.0 & 0 & 0.0 & 0 & 0.0 \\
\hline $13-19$ & 5 & 3 & 60.0 & 0 & 0.0 & 0 & 0.0 \\
\hline $20+$ & 21 & 18 & 85.7 & 1 & 5.6 & 2 & 11.1 \\
\hline
\end{tabular}

focus for onchocerciasis, thus generating a new endemic focus. The Blacks originally settled in the coastal regions of Ecuador, but with their rapidly growing population, have also migrated inland along the rivers, establishing the communities of La Boca, Guayabal, and most recently, Salidero.

Currently, La Ceiva has the highest prevalence of infection of $51.5 \%$. The infection was detected in children who have always lived in the area, indicating that active transmission is occurring in this community. Salidero, located $8 \mathrm{hr}$ upriver from La Ceiva, is the most recently established Black community. Here, some $4.6 \%$ of the population was infected with $O$. volvulus, and all were adults. It is possible that the adults acquired the infection elsewhere. However, the presence of seropositive individuals without detectable dermal microfilariae might also suggest that transmission is occurring and that these individuals are prepatent. In contrast, in Guayabal, though $9.1 \%$ of the sampled population were seropositive, they also were positive for microfilariae in their skin snips. This might indicate that the infection was acquired elsewhere and that there is no active transmission in this community. Further work is required to determine what vectors are active in this region. This might explain the possible differences in transmission be- tween communities.

The fact that no evidence of $O$. volvulus infection was seen on the rivers Mataje, Palaví, Bogotá is in contrast to that reported in 1989 (Guderian \& Shelley 1992). In reviewing the census taken during the two studies, very few of those studied in 1989 were present in the area in 1994. Those tested positive for the infection in 1989 have left the area, with the majority now residing in the large coastal city of Guayaquil. Even though the vector is present in the region, the absence of a human reservoir in these communities may have interrupted transmission. It is unlikely that the infection has extended into Colombia as none of the border communities studied showed evidence of infection. Epidemiological studies are in progress to evaluate the status of the Colombian communities located adjacent to the Ecuadorian focus.

Based on the results of this study, only the communities of La Boca, Guayabal, La Ceiva, and Salidero, on Río Tululví, will be included into the National Control Program for onchocerciasis. It is imperative that distribution of ivermectin begin as soon as possible in order to prevent the infection extending into the Awa Amerindian communities on the rivers Palaví and Mataje. Prompt treatment will also prevent the development of serious disease in any of the affected communities. 
In conclusion, this study has shown that the infection in the cantón San Lorenzo is confined to the Río Tululví area, and there is no evidence of it having extended north to the Colombianecuadorian border. With the introduction of the ivermectin distribution program, the risk of the disease spreading into Colombia from Ecuador is virtually eliminated.

\section{REFERENCES}

Bradley JE, Helm R, Lahaise M, Maizels RM 1991. cDNA clones of Onchocerca volvulus low molecular weight antigens provide immunologically specific probes. Mol Biochem Parasitol 46: 219-228.

Bradley JE, Trenholme KR, Gillespie AJ, Guderian RH, Titanji V, Hong Y, McReynolds L 1993. A sensitive serodiagnostic test for onchocerciasis using a cocktail of recombinant antigens. Am J Trop Med Hyg 48: 198-204.

Carvajal HL, Zerega F 1980. La Oncocercosis en Ecuador: primer caso demostrado. Rev Ecuat Hig Med Trop 33: 1-12.

Collins RC, Brandling-Bennett AD, Holliman RB, Campbell CC, Darsie RF 1980. Parasitological diagnosis of onchocerciasis: comparisons of incubation media and incubation times for skin snips. $\mathrm{Am}$ J Trop Med Hyg 29: 35-41.

Guderian RH, Shelley AJ 1992. Onchocerciasis in Ecuador: the situation in 1989. Mem Inst Oswaldo Cruz 87: 405-415.

Guderian RH, Beck BJ, Proaño R 1990. Onchocerciasis in Ecuador: infection in children in the Santiago Basin focus, province of Esmeraldas. Trans $R$ Soc Trop Med Hyg 84: 109-112.

Guderian RH, Anselmi M, Proaño SR, Herdoiza VM 1988b. Oncocercosis en el Ecuador: prevalencia y distributión desde el Río Santiago al Río Mataje, provincia de Esmeraldas. FCM-Rev Fac Cien Med (Quito) 13: 49-58.

Guderian RH, Beck BJ, Proaño R, Mackenzie CD 1989. Onchocerciasis in Ecuador, 1980-1986: epidemiological evaluation of the disease in the Esmeraldas province. Eur J Epidem 5: 294-302.

Guderian RH, Beck BJ, Stone DJ, Isabel K, Mackenzie CD 1988a. Onchocerciasis in Ecuador: recent observations in the province of Esmeraldas. J Trop Med Hyg 91: 161-168.

Guderian RH, Molea J, Carrillo DR, Proaño SR, Swanson WL 1984. La Oncocercosis en el Ecuador. III. Manifestaciones clínicas de la enfermedad en la provincia de Esmeraldas. FCM-Rev Fac Cien Med (Quito) 9: 9-17.

Guderian RH, Molea J, Swanson D, Proaño R, Carrillo R, Swanson WL 1983. Onchocerciasis in Ecuador. I. Prevalence and distribution in the province of Esmeraldas. Tropenmed Parasit 34: 143-148.

Guderian RH, Proaño R, Milhon JL, Johnson DE, Herdoiza VM 1987. Oncocercosis en el Ecuador: Epidemiologia de los seis focos satelites de la provincia de Esmeraldas. Rev Med Vozandes (Quito) 1: $9-25$.

Shelley AJ, Arzube M 1985. Studies on the biology of Simuliidae (Diptera) at the Santiago onchocerciasis focus in Ecuador, with special reference to the vectors and disease transmission. Trans $R$ Soc Trop Med Hyg 79: 328-338.

Shelley AJ, Arzube M, Couch CA 1989. Simuliidae (Diptera) of the Santiago onchocerciasis focus of Ecuador. Bull Brit Mus Nat His (Entomology) 58: 79-130.

WHO - World Health Organization 1991. Strategies for ivermectin distribution through primary health care systems. WHO/PBL/91.24. 